\title{
A qualitative risk assessment of factors contributing to foot and mouth disease outbreaks in cattle along the western boundary of the Kruger National Park
}

\author{
F. Jori ${ }^{(1,2)}$, W. Vosloo ${ }^{(5,6)}$, B. Du Plessis ${ }^{(3)}$, R. Bengis ${ }^{(4)}$, D. Brahmbhatt ${ }^{(8)}$, \\ B. Gummow ${ }^{(2,9)} \&$ G.R. Thomson ${ }^{(7)}$
}

(1) International Centre for Research, Development and Agronomy (CIRAD), Integrated Animal Risk Management Unit (AGIRs), ES Department, 34398 Montpellier, France

(2) Section of Epidemiology, Faculty of Veterinary Science, University of Pretoria, Onderstepoort, South Africa

(3) Animal Health, Ehlanzeni Region, Nelspruit, Mpumalanga Province, South Africa

(4) Kruger National Park, Department of Agriculture, Directorate of Animal Health, Skukuza, South Africa

(5) Transboundary Animal Disease Programme, Agricultural Research Council, Onderstepoort Veterinary Institute, Onderstepoort, South Africa

(6) Department of Tropical Veterinary Diseases, Faculty of Veterinary Science, University of Pretoria, South Africa

(7) Southern African Development Community - Foot and Mouth Disease Project,

Private Bag 0095, Gaborone, Botswana

(8) Department of Veterinary Integrative Biosciences, Texas A\&M University,

College Station, Texas 77843, United States of America

(9) School of Veterinary and Biomedical Sciences, James Cook University,

Townsville 4811, Queensland, Australia

Submitted for publication: 30 November 2007

Accepted for publication: 5 June 2009

\section{Summary}

Between November 2000 and the end of 2007, five outbreaks of foot and mouth disease (FMD) occurred in cattle in the area adjacent to the Kruger National Park (KNP) in the north-eastern corner of South Africa. To help understand the factors behind these outbreaks a qualitative risk assessment based on the World Organisation for Animal Health (OIE) assessment framework was adopted, using available data from published sources and various unpublished South African sources. Risk was assessed on the basis of the following factors: data on South African Territories (SAT) type infections of buffalo and impala in the KNP, permeability of the fence along the western boundary of the KNP, the potential for contact between livestock and wildlife susceptible to FMD in areas adjacent to the KNP, and the level of herd immunity in cattle generated by prophylactic vaccination. Scenario pathways for FMD occurrence outside the KNP are presented as a conceptual framework to qualitatively assess the risk of FMD outbreaks. Factors that are likely to have most influence on the risk were identified: fence permeability, vaccination coverage, or the efficiency of animal movement control measures. The method and results are provided as an approach that may be used as a basis to evaluate the risk of FMD outbreaks occurring in other wildlife/livestock interface areas of southern Africa.

\section{Keywords}

African buffalo - Foot and mouth disease - Qualitative risk assessment - Southern Africa - Transmission - Wildlife/domestic interface. 


\section{Introduction}

The occurrence of foot and mouth disease virus (FMDV) in South Africa is normally confined to the free-living African buffalo (Syncerus caffer) population of the Kruger National Park (KNP) and associated private conservation areas in the north-eastern corner of the country. Within the KNP, all three South African Territories viruses (SAT 1,2 and 3) are efficiently maintained by buffalo (29). Prior to 2000, the last outbreak of the disease in domestic stock in the FMDfree zone had occurred in 1957 and vaccination was only practised in a small region along the western and southern borders of the KNP. Under these circumstances, the country successfully applied to the World Organisation for Animal Health (OIE) in 1995 for a zone to be recognised as free of FMD without vaccination (free zone in Fig. 1). The KNP and adjacent wildlife areas are recognised as the FMD-infected zone of the country. Adjacent to the western and southern borders of this infected zone is the buffer zone, which has two sections: a portion where animals are vaccinated twice yearly (referred to as the buffer zone with vaccination $[\mathrm{BZV}]$ ) and a portion where animals are not vaccinated but where increased surveillance and movement control are implemented, known as the buffer zone without vaccination (BZNV). Adjacent to the latter is an inspection zone, where increased surveillance is implemented through the inspection of domestic livestock every 28 days. Free movement of animals is permitted within the inspection zone and from it to the FMD-free zone of the country. In the infected zone, BZV and BZNV (together comprising the FMD-control zone), various levels of restriction on animal movement are enforced, while in the FMD-free zone of the country restrictions are not applied (Fig. 1).

For many years the South African animal health authorities have efficiently contained SAT-type viruses within the FMD-control zone by applying control and preventive measures consisting of:

- a $400 \mathrm{~km}$ game-proof perimeter fence along the western boundary of the KNP in both Limpopo and Mpumalanga Provinces

- zoning, as explained above

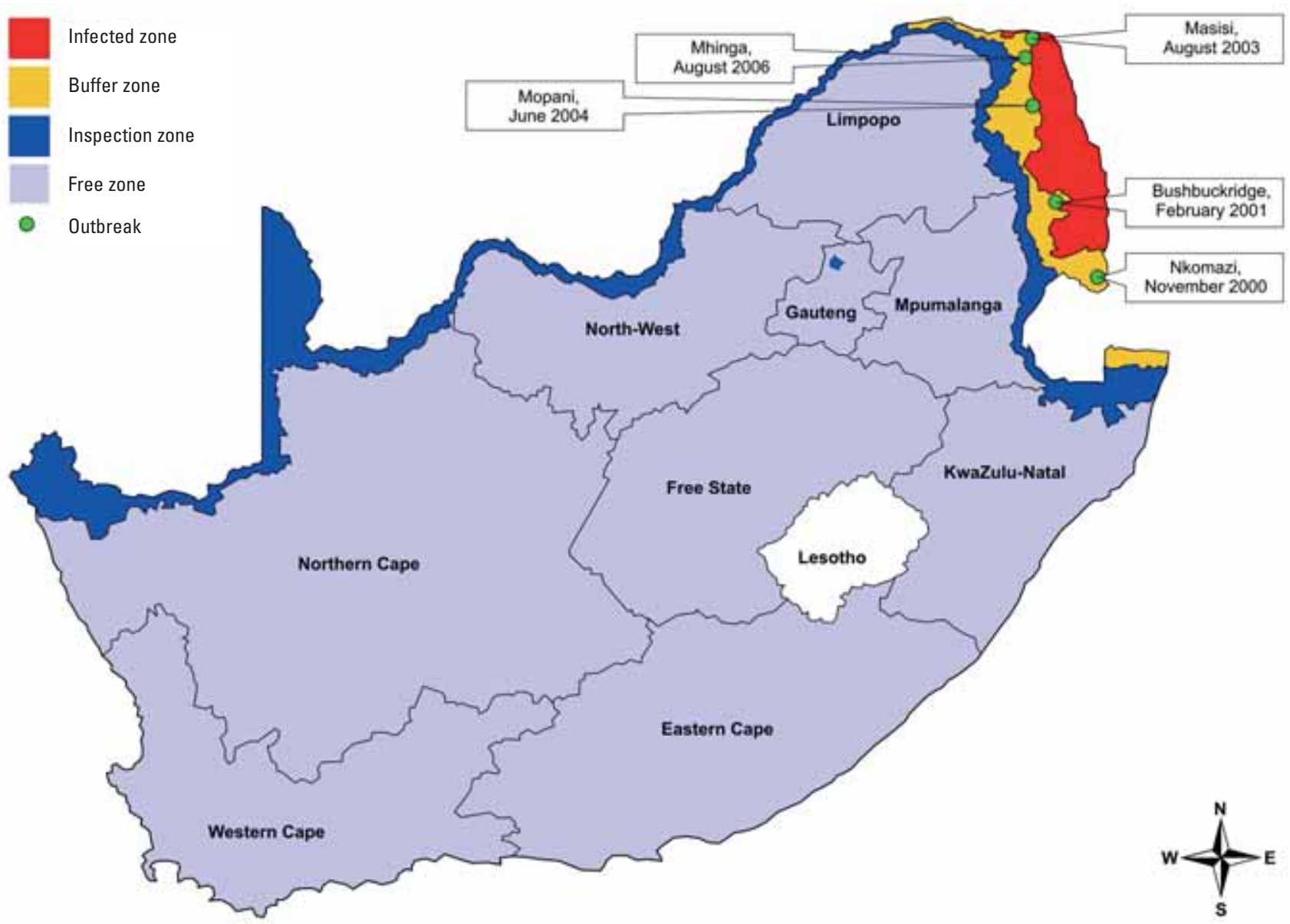

Fig. 1

Foot and mouth disease control zones in South Africa defined in 2005, including all reported outbreaks since the year 2000

The buffer zone includes the buffer zone with vaccination and the buffer zone without vaccination 
- intensive surveillance by means of regular physical inspection of cattle in the buffer and inspection zones

- limiting and strictly controlling the movement of cloven-hoofed animals and their products out of and between the various zones.

Prior to November 2000, the last outbreak of FMD in livestock in the buffer zone had occurred in 1983. However, between 2000 and 2007 five outbreaks, with confirmed epidemiological connection to the KNP, occurred along the western boundaries of the KNP (Fig. 1; 33, 34), some reaching the perimeter of the free zone, threatening agricultural exports on one occasion. Despite these outbreaks, South Africa regained and maintained its FMD-free zone status by complying with the requirements of the OIE's Terrestrial Animal Health Code (40). The possible reasons for the increased numbers of FMD outbreaks in areas adjacent to the KNP between 2000 and 2007 should be investigated in order to identify and actively manage the risk factors that contributed to this situation. The approach proposed here provides a systematic conceptual framework based on classical risk assessment methods that can be used to identify significant weak points in FMD control strategies. This method could also be applied in future to manage the risk of FMD occurrence in other regions of southern Africa where similar situations exist.

\section{Materials and methods}

Qualitative risk assessment based on OIE guidelines was used to address the problem of FMD outbreaks originating from wildlife along the western boundary of the KNP (41). Risk assessment is based on hazard identification, release assessment, exposure assessment and consequence assessment (16, 26, 42). Once the hazard has been identified, in this case an FMD outbreak in cattle outside the KNP, the overall risk can be assessed as a function of:

a) the probability that an outbreak will occur

b) the magnitude of the consequences of such an occurrence (i.e. the economic impact).

The probability of an outbreak is in turn the product of three factors:

a) the release assessment of FMD virus (FMDV) outside the KNP to adjacent farmland/communal areas

b) the likelihood of exposure of cattle herds to infectious quantities of virus

c) the extent of dissemination of the pathogen prior to detection (transmission plus spread).
The probability of each event along the scenario pathways (Fig. 2 and Fig. 3) was qualitatively assessed using a descriptive scale adapted from Zepeda (42) according to four different levels of risk, as follows:

- negligible: the probability of occurrence of the event is sufficiently low to be ignored, or the event is possible only in exceptional circumstances

- low: the occurrence of an event is a possibility in a minority of cases

- moderate: the occurrence of the event is a possibility in the majority of cases

- high: the occurrence of the event is probable.

Those risk categories were subsequently combined with each other (see Table I) to get a combined estimation of risk.

\section{Table I}

Combination of occurrence probabilities of the parameters considered in the qualitative risk assessment of factors contributing to foot and mouth disease outbreaks in cattle along the western boundary of the Kruger National Park (43)

\begin{tabular}{lllll}
\hline \multirow{2}{*}{ Risk of release } & Negligible & Low & Moderate & High \\
\cline { 2 - 4 } & Negligible & Low & Low & Moderate \\
Low & Low & Low & Moderate & Moderate \\
Moderate & Low & Moderate & Moderate & High \\
High & Moderate & Moderate & High & High \\
\hline
\end{tabular}

The information used to assess the risk was collected from published sources combined with unpublished sources available in South Africa, such as serological surveys, national reports, questionnaires, experimental data and personal field observations.

\section{Results}

The results of the qualitative risk assessment are presented following the classical OIE qualitative approach adopted by different authors $(18,39)$.

\section{Hazard identification}

The present analysis focused on FMD outbreaks occurring along the borders of the KNP caused by viruses with demonstrable phylogenetic connection to isolates derived from buffalo in the KNP (SAT 1, SAT 2 and SAT 3). Since impala (Aepyceros melampus) have been reported to be involved in the epidemiology of FMD in the KNP, they have also been included in this assessment (37). 


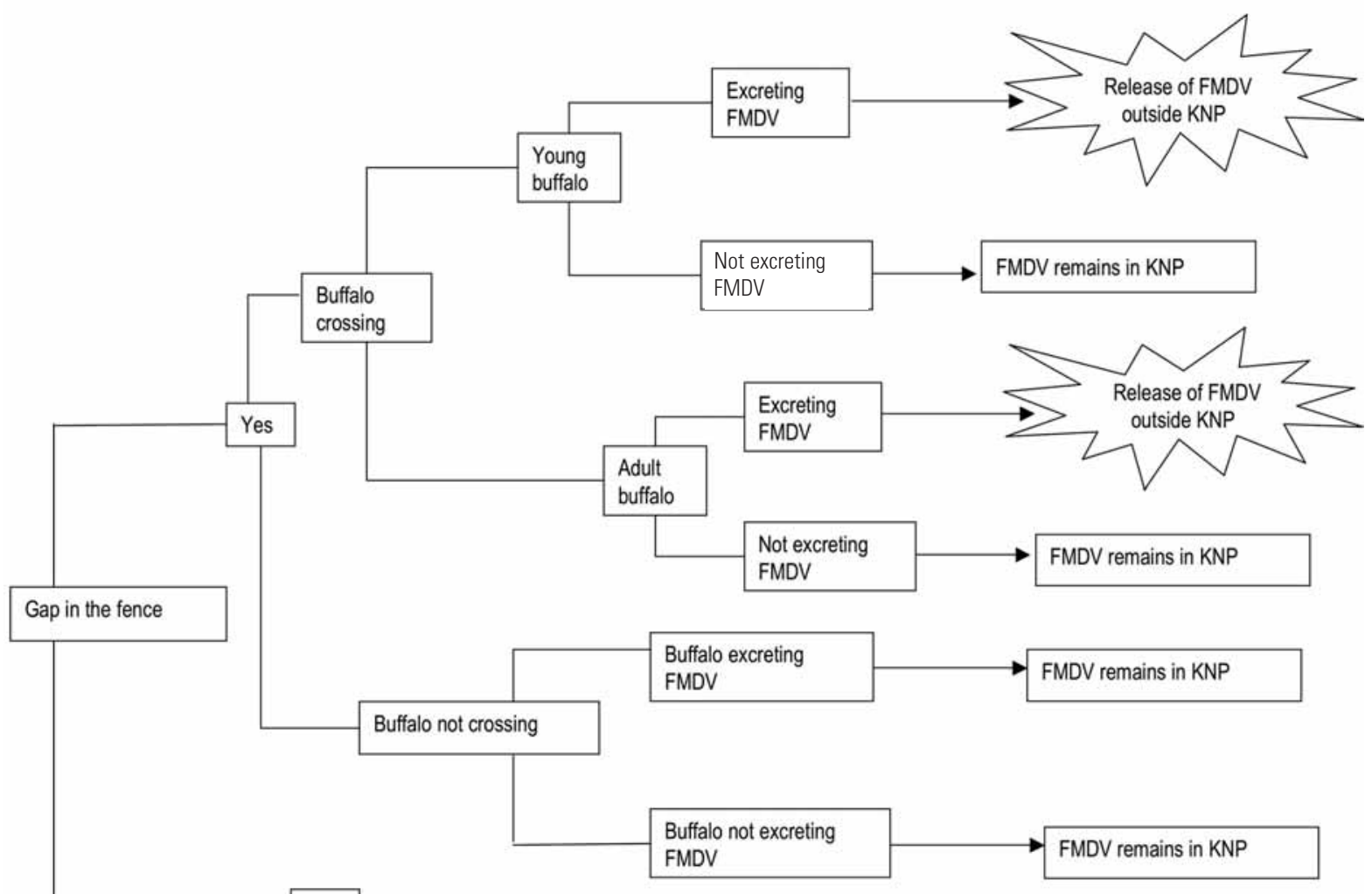

No

FMDV: foot and mouth disease virus

KNP: Kruger National Park

Fig. 2

Possible pathway of release of the foot and mouth disease virus outside the boundaries of the Kruger National Park by escaped buffalo

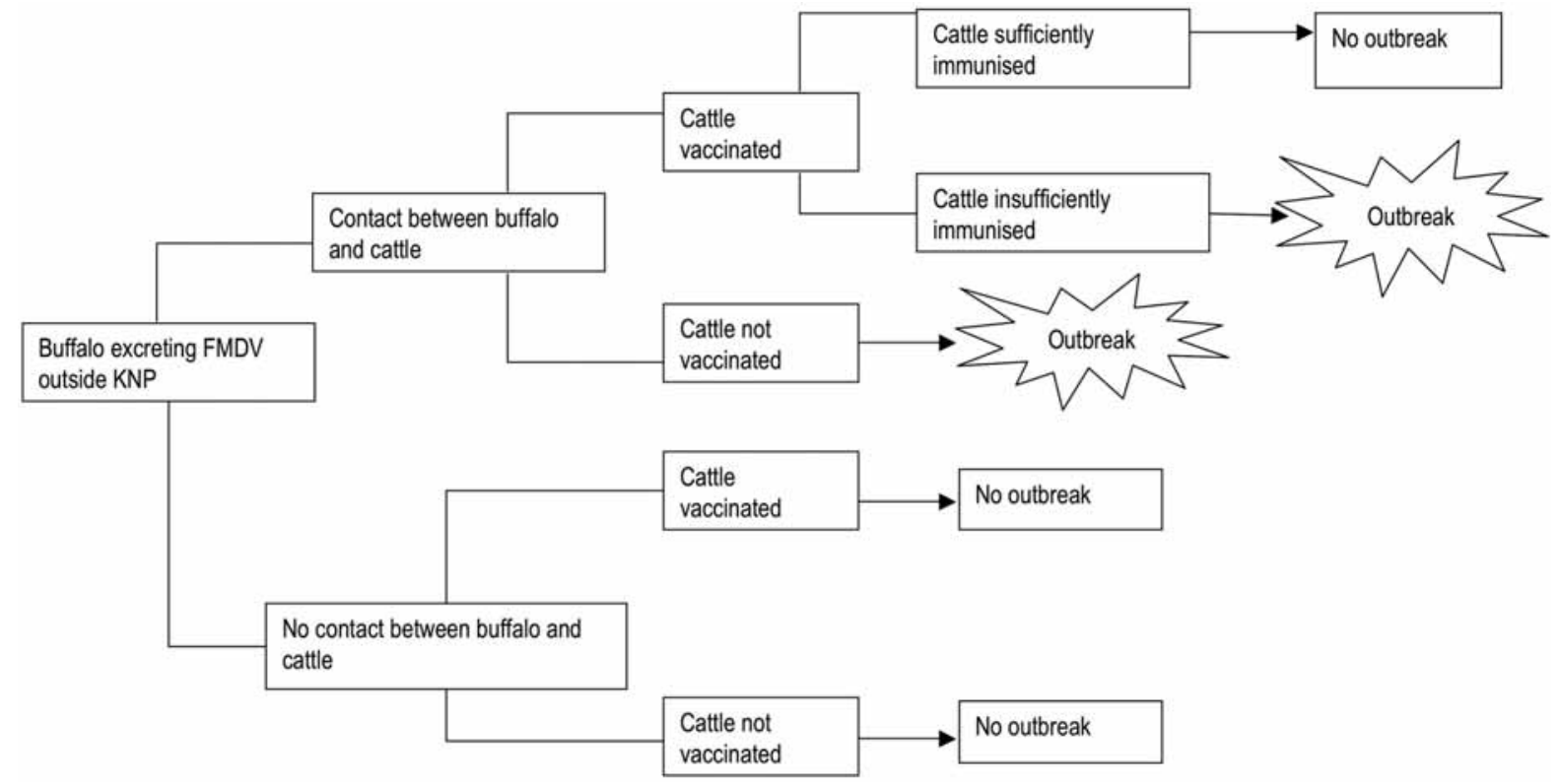

FMDV: foot and mouth disease virus

KNP: Kruger National Park

Fig. 3

Possible pathway of transmission of foot and mouth disease virus from buffalo to cattle and subsequent spread outside Kruger National Park 
The analysis specifically targeted the introduction of FMDV into the cattle herds through contacts between live animals. Release of and exposure to FMDV through the movement of animal products were not considered because the scenario pathways, routes of exposure and methods of prevention and control are different and therefore require specific approaches $(11,38)$.

The risk analysis framework presented here was based on several assumptions that are specific to the South African context. For instance, kudu (Tragelaphus strepsiceros) were not considered potential role players in our scenario pathway for FMDV transmission from wildlife to cattle. Although kudu are susceptible to FMDV and have been reported to be infected in both South Africa (30) and Zimbabwe (C. Foggin, personal communication), available evidence indicates that in the KNP impala are significantly more important in the maintenance and spread of FMD. However, the involvement of kudu has been suspected in other countries (10), and therefore this species, or indeed any other cloven-hoofed species able to cross fences, should not be ignored when assessing FMD risk unless there is reason to do so.

Small ruminants were not considered in the scenarios used either. Despite small ruminants being vaccinated against FMD in South Africa as an additional precaution against virus spread, cumulative data on FMD outbreaks and FMDV circulation in southern and eastern Africa (3) have failed to reveal evidence that sheep or goats are important in the maintenance or transmission of the disease (29).

The level of protection provided by vaccines used for FMD control may have been variable over the last ten years $(21,31,36)$, but for the purpose of simplifying this risk assessment, and due to the lack of information available, we considered vaccine efficacy as being optimal and uniform during this period.

\section{Release assessment}

Three factors were examined to determine the probability of SAT-type viruses crossing the western boundary of the KNP:

- the permeability of the western boundary fence

- reported infection rates of different age-groups of buffalo

- the potential involvement of impala.

The possibility of air-borne transmission of FMDV across the fence in the form of aerosols was not considered for reasons given below (see the section on air-borne virus transmission).

\section{Fence permeability}

The first fence, erected between 1958 and 1961 to prevent contact between wildlife and cattle along the border of the KNP, was apparently successful in helping to prevent FMD outbreaks for almost half a century. This fence was upgraded and electrified between 1997 and 1999 and is currently $400 \mathrm{~km}$ long. In 2000 and 2001 heavy flooding severely damaged a large part of the fence, allowing several hundred buffalo to leave the KNP (Fig. 4). This is assumed to have been at least a contributory factor in the FMD outbreak that occurred in cattle near to the KNP in February 2001 (7). However, the efficiency of the present fence in preventing large mammals from escaping from the KNP seems to have decreased substantially in the last few years due to a combination of factors:

a) A dramatic increase in the elephant population in the KNP (15): it has almost doubled in the last ten years (reaching at least 12,000 individuals) and has resulted in increased elephant-related fence breaks. Although quantitative data on fence breaks are not yet available, high permeability areas have been identified between Punda Maria and Phalaborwa Gates (more specifically around Shangoni camp) and also between Paul Kruger and Malelane Gates (particularly in the vicinity of Phabeni Gate). Fence breaks have been more frequently observed in the dry winter months (June and July) and in periods when maroela trees (Sclerocarya birrea) bear fruit (February and March). In the latter period, up to 25 elephant breaks have been recorded daily in some high permeability areas (R. Bengis, personal communication).

b) Increased human interference with the fence: illegal immigrants (currently estimated to number at least 3,000/year) crossing from neighbouring countries can cause damage to the fence, as can local inhabitants, who sometimes also steal fence components, e.g. batteries and solar panels.

c) Major flooding: flooding has substantially damaged the fence on at least two occasions since 2000 (7, 30). Furthermore, sections of the fence are damaged seasonally at major drainage points and river courses after heavy rain.

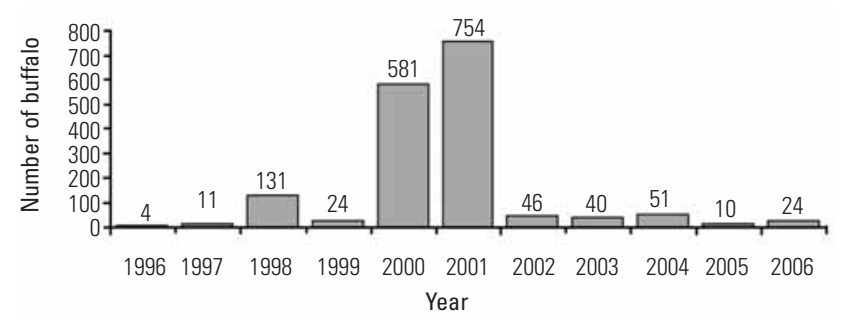

Fig. 4

Number of buffalo that escaped across the perimeter fence of the Kruger National Park in Mpumalanga Province between 1996 and 2006 
Specific quantitative data concerning fence breaks and the number of animals that cross into and out of the Park are being collated but are not yet available. However, preliminary data suggest that more than a thousand fence breaks occur per year and that at least $70 \%$ of all fence breaks occur in the high permeability areas mentioned above. Reports from the Directorate of Veterinary Services in the KNP estimate that over the last six years an average of 80 buffalo have escaped each year. This is consistent with reports from the National Veterinary Services (8) on stray buffalo leaving the KNP across the portion of the fence bordering Mpumalanga Province in the last decade (Fig. 4). Most buffalo crossings occur along the western boundaries of the KNP adjacent to communal lands where the fence is often more permeable due to human damage or frequent elephant breaks. Twelve per cent of the escaping buffalo have been reported to be calves following their mothers (8). Buffalo calves up to about one year of age are important in the transmission of FMDV, as will be explained below. The probability of groups of individual adult buffalo leaving the KNP is therefore considered to be high, but the probability of these groups containing young animals is considered to be low.

\section{Excretion of foot and mouth disease virus by buffalo}

The population of buffalo in the KNP has been increasing since the early 1990s; currently the population (between 30,000 and 33,000) is higher than at any time in the last 14 years $(15,35)$. Most young buffalo, which are born mainly during mid-summer (NovemberFebruary), become infected between three and eight months of age, when maternal antibodies wane (29). By the time they reach one year of age, almost 90\% have been infected with FMD and show circulating antibodies to the three SAT serotypes (28). In the acute stages of infection, young buffalo excrete FMDV in roughly the same quantities and by the same routes as infected cattle and are potentially highly contagious (9). Within 14 days of infection, the virus can no longer be recovered from the tissues, secretions or excretions, with the exception of cells in the pharyngeal mucosa, where the virus may persist for extended periods of time, resulting in 'carriers' $(12,29)$. Limited information exists on the proportion of carrier animals in buffalo herds. The results of one investigation on the persistence of virus in captive individual buffalo after an FMD outbreak showed that $70 \%$ of the infected animals harboured virus in the oropharyngeal area for one to four months after suspected infection (35). This figure progressively decreased to $40 \%$ five months after infection, and six months after the outbreak, virus was isolated from only $17 \%$ of the animals (35). The ability of buffalo to carry FMDV therefore decreases progressively with age, and the ability of carrier animals to transmit the infection is considerably lower than that of acutely infected animals (27).
Between the months of May and November, when water is scarce in the Park, buffalo congregate around available water points (13). At that time, large numbers of susceptible young animals, born synchronously during the mid-summer months, are likely to be actively infected (5, 30). Nevertheless, they will only excrete FMDV for a short period of time. Furthermore, the proportion of young buffalo among the total buffalo population of the KNP is estimated to be $15 \%$ (17). Therefore if the probability of young buffalo excreting FMDV (high) is combined with the probability of young buffalo crossing the fence (low), the resulting risk is moderate. Similarly, the probability of adult buffalo crossing the fence is high, but since the probability that they will excrete virus is negligible, the combined risk is assessed as moderate (see Table II).

\section{Release of foot and mouth disease virus by other cloven-hoofed species}

Infection of impala with FMDV in the KNP occurs periodically $(5,30,32,37)$, and genetic analysis of virus isolates has shown unequivocally that buffalo are the source of infection. Impala are highly susceptible to FMDV, but they do not become persistently infected (26). However, during the acute phase of the disease, which lasts for approximately five days $(13,35)$, infected animals excrete virus in all body secretions, and a retrospective study comparing FMDV isolates obtained from impala and cattle demonstrated that disease had spread from impala to cattle on a number of occasions in the past (32). During impala outbreaks it has been found that $18 \%$ to $25 \%$ of the affected herd can become infected (although only a proportion of those animals develop clinical disease) $(13,26)$. However, since the 1990s, clinical outbreaks of FMD in impala in the KNP have declined in frequency and only one outbreak with clinical signs has occurred in the last ten years (37). Therefore, although serological evidence indicates that the virus circulation in the impala population might be more frequent than previously recognised, the probability of there being an infectious impala among the more than 100,000 individuals living in the KNP is currently low. Analysis of a recently conducted questionnaire indicated that a greater number of impala than buffalo cross the fence (F. Jori, unpublished data). This is supported by the fact that impala are able to jump $2.4 \mathrm{~m}$ fences (10). Combining this information suggests that the probability of impala escaping from the KNP is high but the probability of an impala being infectious at the time of escape is low. The probability of FMDV release by impala is therefore moderate.

\section{Probability of virus release when cattle enter the Kruger National Park premises}

Occasionally herds of cattle are intentionally driven into or opportunistically enter the KNP in search of pasture, particularly in the dry season. They are usually chased 
Table II

Summary of the assessment of risk of foot and mouth disease virus release outside Kruger National Park and subsequent spread in the buffer zone with vaccination

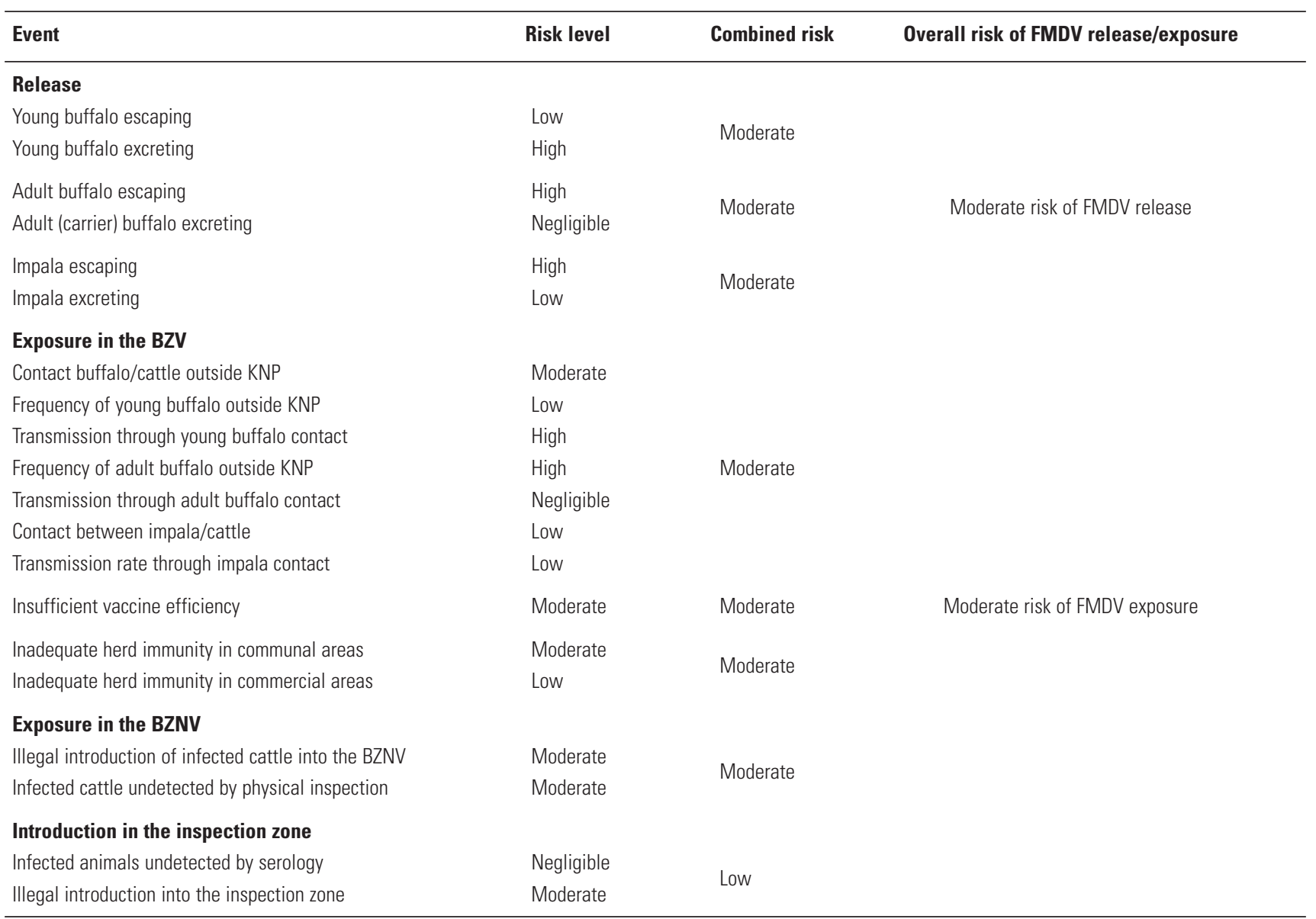

BZV: Buffer zone with vaccination

BZNV: Buffer zone without vaccination

KNP: Kruger National Park

FMDV: Foot and mouth disease virus

back promptly by veterinary staff or KNP personnel. Staff report that contact with buffalo herds rarely occurs inside the Park. This assessment has been supported by a recent survey among fence workers, who only observed contact between cattle and wildlife in the KNP on $8 \%$ of the occasions when cattle entered the Park (F. Jori, unpublished data). The probability of cattle coming into close enough contact with buffalo in the KNP to enable FMDV transmission is therefore low.

\section{Overall release assessment}

Figure 2 illustrates a possible scenario pathway for the release of FMDV outside the KNP. Using the matrix proposed in Table I (42), the authors conclude that the probability of FMDV release outside the KNP is a function of the probability of buffalo and impala crossing the fence (high) and the probability that the same individuals are acutely infected (low). The combined risk for FMDV release outside the KNP by wildlife is therefore rated as moderate (see Table II). The risk of cattle entering the KNP through fence gaps and returning with FMD infection resulting from contact with buffalo is low.

\section{Probability of exposure of livestock to foot and mouth disease virus in the various control zones adjacent to the Kruger National Park}

The scenarios considered in determining the probability of livestock becoming infected as a result of exposure to FMD virus were as follows:

- air-borne transmission

- infection of livestock resulting from exposure to wildlife in the BZV

- the probability of spread of disease in the BZV

- the probability of spread of disease in the BZNV

- the probability of virus spread within the inspection zone and onwards (free zone). 


\section{Air-borne virus transmission}

Circumstantial evidence accumulated over many years has indicated that direct contact accounts for most transmission events in southern Africa. No convincing evidence for long-distance air-borne transmission has ever been advanced in sub-Saharan Africa (28). Furthermore, in a quantitative risk assessment conducted in Zimbabwe, the likelihood of this event was assessed as remote (26). That conclusion was therefore adopted for this study.

\section{Contact between infected buffalo and susceptible cattle outside the Kruger National Park}

The population of cattle adjacent to the KNP is approximately $325,000(85,000$ in the BZV plus 240,000 in the BZNV) (Table III). Bearing in mind these numbers, the fact that some buffalo are likely to cross the KNP fence, and the gregarious nature of buffalo, there is a risk of FMDV transmission from buffalo to cattle. Indeed, when buffalo are outside the Park they appear to seek contact with cattle herds. In a recent questionnaire survey among 100 cattle owners in Bushbuckridge (Mpumalanga Province), $24 \%$ of the farmers reported observing buffalo in the BZV and 15\% reported some contacts between escaped buffalo and cattle. The reported duration of contact ranged from an hour (10\% of respondents) to more than $12 \mathrm{~h}$ (4\% of respondents) (N. Abu Samra, personal communication). Young buffalo bulls or small herds (especially groups of heifers and young bulls) that have escaped from the KNP are occasionally observed to have joined a cattle herd, presumably seeking companionship or the protection of conspecifics in a foreign environment (D. Keet, personal communication). Older bulls are less likely to socialise with cattle, although evidence of sexual contact has been reported (4).

\section{Table III}

Number of domestic animals susceptible to foot and mouth disease in the surveillance areas surrounding Kruger National Park (Mpumalanga and Limpopo Provinces)

\begin{tabular}{lrrr}
\hline Zone & Cattle & Sheep & Goats \\
\hline BZV & 84,105 & 2,475 & 37,909 \\
BZNV & 240,709 & 2,901 & 81,646 \\
Inspection zone & 92,172 &, 680 & 31,050 \\
Total & $\mathbf{4 1 6 , 9 8 6}$ & $\mathbf{6 , 0 5 6}$ & $\mathbf{1 5 0 , 6 0 5}$ \\
\hline
\end{tabular}

BZV: Buffer zone with vaccination

BZNV: Buffer zone without vaccination

In contrast to commercial farming areas, contact between buffalo and cattle in the communal farming areas outside the KNP is relatively common, because cattle densities are higher and fences less effective. However, most of these contacts occur during the day because $98 \%$ of the cattle are penned at night in communal areas. In commercial farming areas (which cover only about 20\% of the area immediately outside the KNP), cattle are not usually penned at night, potentially providing buffalo and cattle with more than a day to come into close contact. Taking the above into consideration, it was assumed that the risk of contact between cattle and buffalo is moderate. Moreover, the risk of longer (more than $24 \mathrm{~h}$ ) contact that would enable more efficient transmission of FMD is low.

\section{Foot and mouth disease virus transmission between buffalo and cattle}

Transmission of FMDV from infected buffalo to cattle occurs during close contact and mostly when buffalo (principally young buffalo) are in the acute stages of the disease $(29,30,33)$. The probability of transmission of FMDV when groups of buffalo that include young animals come into close contact with susceptible cattle is therefore high. However, this risk decreases significantly when adult carrier buffalo have close contact with cattle. Tenzin Dekker (27) recently estimated that the transmission rate from carrier animals, including African buffalo, was probably 500 times lower than that estimated for acutely infected animals. The probability of transmission from carrier buffalo to susceptible livestock is therefore likely to be negligible. Equally, the risk of development of clinical disease in cattle exposed to buffalo infected with FMDV decreases when the cattle have been vaccinated (i.e. in the vaccination zone), as long as the level of herd immunity achieved is $80 \%$ or higher $(20,22)$.

\section{Foot and mouth disease virus transmission from impala to cattle}

Despite impala being a susceptible species (1) with a demonstrated role in the epidemiology and transmission of the disease to cattle $(13,33,37)$, the circumstances under which the infection spreads from impala to cattle remain unclear (5). Impala are able to jump fences and graze close to cattle in communal lands adjacent to the KNP (F. Jori, unpublished results); however, when these antelope are infected with FMDV, they excrete smaller quantities of virus than cattle or buffalo and are not considered to be as efficient transmitters of FMDV (13). Moreover, when they cross the fence, they are easily chased by dogs and hunted by local communities (R. Bengis, personal communication). The probability of transmission from impala to cattle was therefore considered to be low.

\section{Spread of foot and mouth disease within the buffer zone with vaccination}

Cattle in the BZV are vaccinated twice a year by trained veterinary officials. Overall, $80 \%$ of the cattle herds are found on communal land and the rest on commercial farms. However, vaccination coverage in the BZV is not constant and can vary between $60 \%$ and $85 \%$ depending on the area and campaign efficiency. Cattle in communal areas are vaccinated at dip tanks, and vaccination is 
dependent on the commitment of communal farmers to take their cattle to their assigned dip tank regularly (25). In addition, the efficiency with which vaccine is administered is important in determining overall herd immunity. In general terms, the probability of a herd being inadequately vaccinated was considered to be low in the case of commercial farms, but moderate in communal areas where control of vaccination programmes is more difficult.

Given these circumstances, the risk of herd immunity (understood as a function of vaccination coverage and vaccine efficacy) being insufficient was considered to be moderate, with communal areas being more problematic than commercial farming areas. The probability of spread of FMDV infection in cattle in the BZV was therefore also assessed as moderate.

Intensive FMD surveillance through physical inspection is undertaken in the BZV at dip tanks by lay persons, technically trained assistants and/or veterinarians. Depending on the age and immune status of the animals as well as the strains of circulating virus, some outbreaks of SAT strains of FMD involving indigenous cattle may be characterised by mild lesions that can be difficult to recognise (14). This situation may be accentuated in cattle herds that have been only partially vaccinated. Therefore, despite the fact that cattle within the BZV are inspected every seven days, the probability of infected animals going undetected is moderate.

\section{Probability of introduction and spread into the buffer zone without vaccination}

Movement of animals from the BZV to the BZNV is allowed after 21 days of quarantine in the BZV, full physical examination of the herd, satisfactory vaccination history of the herd or vaccination of the entire herd. Vaccinated animals in the BZV are branded with an 'F' on the left side of the neck and are only permitted to leave the zone, accompanied by a veterinary permit, to travel directly to designated abattoirs for slaughter.

In the BZNV, cattle are not vaccinated but herd inspection is performed every 14 days. However, as indicated above, in southern Africa the probability of animals going undetected despite physical inspection is moderate. Moreover, there is a price differential between cattle inside and outside the BZV, the price of cattle being higher in the BZNV and the zones beyond it. There is therefore an incentive to sell cattle illegally outside the BZV. This problem is exacerbated by the fact that cattle are not individually identified in most herds and, despite animal movement control points at the gates between the various zones, the level of risk of cattle being smuggled out of the BZV was considered to be moderate.

\section{Possibility of foot and mouth disease virus being introduced into the inspection zone}

Movements of cloven-hoofed livestock out of the BZNV are only permitted after demonstration of "no vaccination history', satisfactory inspection history, individual identification of the animals, and negative serological tests for all 3 SAT serotypes after 21 days in quarantine. The enzyme-linked immunosorbent assay (ELISA) used is able to detect animals that might have been infected and have recovered or are in the process of recovery (the sensitivity and specificity of the screening ELISA are 95\% and 98\% respectively) (National Directorate for Animal Health, unpublished), or that have been vaccinated and illegally introduced from the BZV. Any serologically or clinically suspicious animal is tested again using a non-structural viral protein $\operatorname{ELISA}(19,23)$ in order to distinguish between infected and vaccinated animals. In those circumstances, the probability of an infected animal going undetected during the 21 days of quarantine is negligible. However, there is a possibility that animals from the BZNV will be moved illegally to obtain higher prices. In the last five years, an average of three instances of illegal movement per year were detected in the Mpumalanga Province alone, with an average of 60 animals per movement (8). This indicates that some illegal movement occurs but the level of detection is unknown. Other available information suggests that this could be a serious contributing factor to disease spread (7). The risk of cattle from the buffer zone reaching the inspection zone is considered to be low, based on the combined risks of cattle being undetected by serological surveillance (negligible) and the likelihood of an animal being smuggled out of the BZNV and onwards (moderate).

\section{Overall exposure assessment}

Table II presents the list of probabilities considered in this assessment. Pathways delineating the most plausible routes of transmission from buffalo to cattle are presented in Figure 3. The resulting probability of transmission from contacts between wildlife and livestock outside the KNP was rated as moderate. Also considered to be moderate was the probability of outbreak occurrence and spread within the BZV in communal areas. However, this would ultimately depend on the level of herd immunity generated by vaccination. The probability of introduction into the BZNV, considering the potential importance of illegal movements and lack of traceability of the animals, was considered to be moderate. Probability of spread within the BZNV, essentially dependent on failure of early detection by physical inspection (moderate) combined with the probability of herd immunity being insufficient (moderate), was also rated as moderate. The combined probability of the above events resulting in infected animals moving from the BZNV 
to the inspection zone was considered to be moderate, bearing in mind the application of control measures, including serological surveillance, which lowered the risk, and the occurrence of undetected illegal movement, which raises it.

\section{Magnitude of consequences}

In terms of economic impact foot and mouth disease is the most important livestock disease in southern Africa (28). An outbreak of FMD outside the KNP would not result in high mortality but it would have an effect on beef exports. The severity of the impact on international trade would depend on the region of the country where the outbreak occurred or spread to (Table IV) and on the perception of the disease and its management by a diversity of interest groups. In the infected zone or BZV the impact of disease is likely to be limited, since these zones lie within the FMD control area and livestock numbers are also low (Table III), with few commercial farms. In the BZNV, the impact would be higher than in the BZV, because there is more livestock, but it is still within the FMD control area. Outbreaks in the inspection zone and beyond would have serious economic implications because South Africa would lose its zonal FMD-free status for international trade in livestock and livestock products. For example, the cost of the outbreaks that occurred during 2000 and 2001 in the FMD-free zone of South Africa was estimated to be the equivalent of US\$9 million (7).

\section{Table IV}

Economic consequences of a foot and mouth disease outbreak according to the zones

\begin{tabular}{lcl}
\hline Scenario & $\begin{array}{c}\text { Impact of } \\
\text { consequences }\end{array}$ & $\begin{array}{l}\text { Significance at } \\
\text { international level }\end{array}$ \\
\hline Outbreak in BZV & Low & $\begin{array}{l}\text { Low: no change in the } \\
\text { country's animal disease } \\
\text { status } \\
\text { Low: no change in the } \\
\text { country's animal } \\
\text { disease status }\end{array}$ \\
$\begin{array}{ll}\text { Outbreak in BZNV } \\
\begin{array}{l}\text { Outbreak in } \\
\text { inspection zone } \\
\text { or beyond }\end{array}\end{array}$ & Moderate & $\begin{array}{l}\text { High } \\
\text { status for the whole } \\
\text { of South Africa }\end{array}$ \\
\hline
\end{tabular}

BZV: Buffer zone with vaccination

BZNV: Buffer zone without vaccination

FMD: Foot and mouth disease

\section{Discussion}

This risk assessment provides a framework for the qualitative estimation of risk for the occurrence of FMD outbreaks along the western boundary of the KNP. The OIE risk analysis framework adopted for this study is based on the guidelines for management of disease risks associated with the import of live animals or animal products (39). The paper applies qualitative risk assessment in the context of South Africa's FMD situation, which involves an endemic region centred on the KNP. It is the first published risk assessment to consider a number of important factors and chains of events likely to be involved in the occurrence of FMD outbreaks of wildlife origin in this area. Although the information presented is not new, this study provides a framework integrating the disparate and diverse issues associated with FMD at the wildlife/livestock interface in southern Africa. The overall assessment provided shows that the risk of an FMD outbreak occurring in livestock adjacent to the KNP is moderate (see Table V). Factors that could precipitate an outbreak in the study area and that should be addressed are:

- the permeability of the KNP perimeter fence

- the risk of low levels of herd immunity in cattle herds in the BZV, especially in communal areas

- the efficiency with which regulations pertaining to the control of FMD in areas adjacent to the KNP are implemented

- the price differential between cattle inside the control zone as opposed to those outside the control zone, i.e. the economic incentive for illegal cattle movement.

\section{Table V}

Overall estimation of risk considering the combined risk of foot and mouth disease outbreak occurrence and the varying consequences of that outbreak depending on the zone in which it occurs

\begin{tabular}{lccc}
\hline Zone & $\begin{array}{c}\text { Combined probability } \\
\text { of outbreak } \\
\text { occurrence }\end{array}$ & Consequences & Risk estimation \\
\hline BZV & Moderate & Low & Moderate \\
BZNV & Moderate & Moderate & Moderate \\
Inspection zone & & High & Moderate \\
\hline
\end{tabular}

BZV: Buffer zone with vaccination

BZNV: Buffer zone without vaccination

Permeability of the KNP perimeter fence would be reduced by improved fence monitoring and more rapid repair of breaks when they occur. Elephant damage to the fence is a major factor and strategies for the control of elephant populations, although contentious, are under consideration in South Africa (6). Furthermore, a more solid, non-electrified fence, able to resist elephant damage, is being built and is progressively replacing the old fence from the north to the south of the KNP (between Punda Maria and Phalaborwa) (D. Keet, personal communication). 
Efforts to improve the traditional dip-tank system, aimed primarily at tick control but also providing excellent opportunities for physical inspection (surveillance), are underway along the western boundary of the KNP. The successful control of outbreaks that occurred in recent years demonstrated that active surveillance and effective contingency plans assisted significantly in identifying and containing the disease before it reached the free zone, preserving South Africa's official FMD-free status (7).

It is, however, difficult to retain the cooperation of local livestock owners in the absence of compensation or inducements. This is because not only are their animals worth less than animals in the FMD-free areas, but also because they must implement FMD control measures for the benefit of the rest of the country where FMD is not endemic. Provision of a free dipping service has helped to some extent. However, this social dimension, often overlooked, clearly has an impact on the efficiency of FMD control (29). Furthermore, the disparity in the value of livestock between the control and free zones provides a clear incentive for illegal activity that could endanger effective FMD control.

Other approaches that could improve the efficiency of current FMD control systems are the regular auditing of the control and surveillance measures in place in order to identify those that are deficient, and periodic re-evaluation of risk assessments based on a 'risk-based surveillance' approach (24).

\section{Conclusion}

The assessment of risk presented here focuses on details of the linkages between the factors that should be considered when FMD outbreaks occur in this region of South Africa. However, the risk of occurrence of the scenarios presented and the overall assessment of risk must be interpreted with caution because the accuracy of available information is limited. For example, the information about contacts between wildlife and livestock is based on field observation of species proximity. The closeness and type of interaction between different species required for efficient transmission of FMDV from an infectious to a susceptible animal under natural conditions remain speculative.

While the qualitative approach adopted in this study has clear limitations, especially with respect to risk categorisation, it has the advantage of being simple, based on well-described and accepted methodology, and easy to communicate. It is also a useful tool for assessing the efficiency of disease management and control options and for identifying gaps in our understanding of the important factors governing FMD occurrence. Moreover, it is a preliminary step in the process of building more sophisticated qualitative or quantitative risk models.

In summary, the approach adopted in this study provides a baseline framework for estimating the risk of FMD outbreaks at the wildlife/domestic animal interface on the boundaries of wildlife conservation areas that may be usefully implemented in other parts of southern Africa.

\section{Acknowledgements}

We are very grateful to Drs Willie Ungerer and Grietjie De Klerk from the National Veterinary Services and Erika Kirkbride from the Exotic Diseases DivisionOnderstepoort Veterinary Institute for providing reports and information on recent outbreaks. We would like to acknowledge Dr Edwin Dyason for providing information on Limpopo Province and Dr Dewald Keet for his information about the northern part of the KNP fence. We are very grateful to Dr Mary-Louise Penrith for the final editing of the manuscript. 


\title{
Évaluation qualitative des facteurs de risque d'apparition de foyers de fièvre aphteuse chez les bovins vivant à la limite occidentale du Parc national du Kruger, Afrique du Sud
}

\author{
F. Jori, W. Vosloo, B. Du Plessis, R. Bengis, D. Brahmbhatt, \\ B. Gummow \& G.R. Thomson
}

\begin{abstract}
Résumé
Cinq foyers de fièvre aphteuse ont été signalés entre novembre 2000 et janvier 2009 chez des bovins vivant dans la zone adjacente du Parc national du Kruger (KNP), situé au nord-est de l'Afrique du Sud. Une évaluation qualitative du risque basée sur la méthode d'analyse de risque qualitative proposée par l'Organisation mondiale de la santé animale (OIE) a été entreprise afin de comprendre l'importance des différents facteurs favorisant l'apparition de ces foyers, en utilisant les informations publiées ainsi que des données émanant de plusieurs sources non publiées d'Afrique du Sud. Les facteurs de risque suivants ont été considérés : informations relatives aux infections dues aux sérotypes SAT (South African Territories) chez les buffles et les impalas du KNP ; perméabilité des clôtures le long de la limite occidentale du KNP ; possibilités de contact entre le bétail domestique et la faune sauvage sensible au virus de la fièvre aphteuse dans les zones adjacentes du KNP ; niveau d'immunité à l'échelle du troupeau chez les bovins suite à la vaccination préventive. Les scénarios associés à l'apparition de la fièvre aphteuse à l'extérieur du KNP ont été utilisés comme modèle événementiel pour évaluer qualitativement le risque d'apparition de foyers. Les facteurs identifiés comme ayant la plus grande influence sur ce risque sont : la perméabilité des clôtures, le niveau de couverture vaccinale et le niveau d'efficacité des mesures de contrôle des mouvements d'animaux. Les auteurs considèrent que cette méthode et les résultats obtenus peuvent servir de base pour évaluer le risque d'apparition de foyers de fièvre aphteuse dans d'autres régions d'Afrique australe où les populations d'animaux domestiques vivent au contact d'animaux sauvages.
\end{abstract}

\section{Mots-clés}

Afrique australe - Buffle d'Afrique - Évaluation qualitative du risque - Fièvre aphteuse - Interface animaux sauvages/animaux domestiques - Transmission.

\section{Evaluación cualitativa del riesgo de los factores que inducen brotes de fiebre aftosa en el ganado vacuno a lo largo del límite occidental del Parque Nacional de Kruger, Sudáfrica}

\author{
F. Jori, W. Vosloo, B. Du Plessis, R. Bengis, D. Brahmbhatt,
}

B. Gummow \& G.R. Thomson

\section{Resumen}

Entre noviembre de 2000 y enero de 2009 se dieron cinco brotes de fiebre aftosa en el ganado vacuno de la zona contigua al Parque Nacional de Kruger (PKN), en el extremo nororiental de Sudáfrica. Para tratar de entender mejor los factores que subyacen a esos brotes se llevó a cabo una evaluación cualitativa 
del riesgo basada en el método de análisis de riesgo de la Organización Mundial de Sanidad Animal (OIE), utilizando datos extraídos de publicaciones y de otras varias fuentes sudafricanas inéditas. Se evaluó el riesgo atendiendo a los siguientes factores: datos sobre la infección de búfalos e impalas del PKN por cepas SAT (South African Territories); permeabilidad de la cerca que delimita la frontera occidental del Parque; posibilidades de contacto entre ganado y fauna salvaje susceptible a la fiebre aftosa en zonas adyacentes al Parque; y nivel de inmunidad de los rebaños inducido por la vacunación profiláctica. Como marco teórico para evaluar cualitativamente el riesgo de brotes de fiebre aftosa, los autores utilizaron árboles esquemáticos representando la serie de eventos que se producen para que la enfermedad se dé fuera del Parque. Así se determinaron los factores que con mayor probabilidad influyen en el nivel de riesgo: permeabilidad de la cerca; cobertura de vacunación; y eficacia de las medidas de control de los movimientos de animales. Los autores presentan el método y los resultados como posible esquema que puede servir de base para evaluar el riesgo de brotes de fiebre aftosa en otras zonas de contacto entre la fauna doméstica y la salvaje del África austral.

\section{Palabras clave}

África austral - Análisis de riesgo cualitativo - Búfalo africano - Fiebre aftosa - Interfaz entre fauna salvaje y doméstica - Transmisión.

\section{References}

1. Anderson E.C., Foggin C., Atkinson M., Sorensen K.J., Madekurozva R.L. \& Nqindi J. (1993). - The role of wild animals, other than buffalo, in the current epidemiology of foot-and-mouth disease in Zimbabwe. Epidemiol. Infect., $111,559-563$.

2. Baipoledi E.K., Matlho G., Letshwenyo M., Chimbombi M., Adom E.K., Raborokgwe M.V. \& Hyera J.M.K. (2004). Re-emergence of foot-and-mouth disease in Botswana. Vet. J., 168 (1), 93-99.

3. Barnett P.V. \& Cox S.J. (1999). - The role of small ruminants in the epidemiology and transmission of foot-and-mouth disease. Vet. J., 158 (1), 6-13.

4. Bastos A.D.S., Bertschinger H.J., Cordel C., Vuuren C.D., Keet D., Bengis R.G., Grobler D.G. \& Thomson G.R. (1999). - Possibility of sexual transmission of foot-and-mouth disease from African buffalo to cattle. Vet. Rec., 145 (3), 77-79.

5. Bastos A.D.S., Boshoff C.I., Keet D.F., Bengis R.G. \& Thomson G.R. (2000). - Natural transmission of foot-andmouth disease virus between African buffalo (Syncerus caffer) and impala (Aepyceros melampus) in the Kruger National Park, South Africa. Epidemiol. Infect., 124 (3), 591-598.

6. Beresford D. (2007). - South Africa considers elephant culls. The Guardian (1 March 2007). Available at: http://www. guardian.co.uk/environment/2007/mar/01/southafrica.conser vationandendangeredspecies.
7. Bruckner G.K., Vosloo W., Du Plessis B.J.A., Kmoeck P.E.L.G., Connoway L., Ekron M.D., Weaver D.B., Dickason C.J. et al. (2002). - Foot and mouth disease: the experience of South Africa. In Foot and mouth disease: facing the new dilemmas (G.R. Thomson, ed.). Rev. sci. tech. Off. int. Epiz., 21 (3), 751-764.

8. Du Plessis B. (2007). - Animal health services, Ehalnzeni District. Annual Report 2006, 145 pp.

9. Gainaru M.D., Thomson G.R., Bengis R.G., Esterhuysen J.J., Bruce W. \& Pini A. (1986). - Foot and mouth disease and the African buffalo (Syncerus caffer). II. Virus excretion and transmission during acute infection. Onderstepoort J. vet. Res., 53, 75-85.

10. Hargreaves S.K., Foggin C.M., Anderson E.C., Bastos A.D.S., Thomson G.R., Ferris N.P. \& Knowles N.J. (2004). - An investigation into the source and spread of foot and mouth disease virus from a wildlife conservancy in Zimbabwe. Rev. sci. tech. Off. int. Epiz., 23 (3), 783-790.

11. Hartnett E., Adkin E., Seaman M., Cooper J., Watson E., Coburn E., England T., Marooney C., Cox A. \& Wooldridge M. (2007). - A quantitative assessment of the risks from illegally imported meat contaminated with foot and mouth disease virus to Great Britain. Risk Analysis, 27 (1), 187-202. 
12. Hedger R.S. \& Condy J.B. (1985). - Transmission of footand-mouth disease from African buffalo virus carriers to bovines. Vet. Rec., 117 (9), 205-207.

13. Keet D.F., Hunter P., Bengis R.G., Bastos A. \& Thomson G.R. (1996). - The 1992 foot-and-mouth disease epizootic in the Kruger National Park. J. S. Afr. vet. Assoc., 67 (2), 83-87.

14. Kennedy D., Jackson R.B. \& Ramsay G.C. (1984). Difficulties experienced in recognizing foot and mouth disease in an outbreak in Zimbabwe. Aust. vet. J., $61,163-164$

15. Kruger Park News (2007). - Elephant numbers up by five percent. Online News Publication. Available at: http://www. krugerpark.co.za/krugerpark-times-4-15-elephant24658.html.

16. MacDiarmid S.C. \& Pharo H.J. (2003). - Risk analysis: assessment, management and communication. In Veterinary Services: organisation, quality assurance, evaluation (E. Correa Melo \& F. Gerster, eds). Rev. sci. tech. Off. int. Epiz., 22 (2), 397-408

17. Mlozsewsky M.J. (1983). - The herd. In The behaviour and ecology of the African buffalo. Cambridge University Press, 41-62.

18. Moutou F., Dufour B. \& Ivanov Y. (2001). - A qualitative assessment of the risk of introducing foot and mouth disease into Russia and Europe from Georgia, Armenia and Azerbaijan. Rev. sci. tech. Off. int. Epiz., 20 (3), 723-730.

19. Paton D.J., de Clercq K., Greiner M., Dekker A., Brocchi E., Bergmann I., Sammin D.J., Gubbins S. \& Parida S. (2006). Application of non-structural protein antibody tests in substantiating freedom from foot-and-mouth disease virus infection after emergency vaccination of cattle. Vaccine, 24 (42-43), 6503-6512

20. Pay T.W.F. (1984). - Factors influencing the performance of foot-and-mouth disease vaccines under field conditions. Appl. Virol., 6, 73-86.

21. Rweyemamu M.M., Pay T.W.F. \& Parker M.J. (1977). Serological differentiation of foot-and-mouth disease virus strains in relation to selection of suitable vaccine strains. Dev. biol. Standard., 35, 205-214.

22. Saraiva V. (2003). - Vaccines and foot and mouth disease eradication in South America. In Vaccines for OIE List A and emerging animal diseases (F. Brown \& J. Roth, eds). Karger, Basel, 67-77.

23. Sörensen K.J., de Stricker K., Dyrting K.C., Grazioli S. \& Haas B. (2005). - Differentiation of foot-and-mouth disease virus infected animals from vaccinated animals using a blocking ELISA based on baculovirus expressed FMDV $3 \mathrm{ABC}$ antigen and a $3 \mathrm{ABC}$ monoclonal antibody. Arch. Virol., 150 (4), 805-814
24. Stark K., Regula G., Hernandez J., Knopf L., Fuchs K., Morris R. \& Davies P. (2006). - Concepts for risk-based surveillance in the field of veterinary medicine and veterinary public health: review of current approaches. BMC Health Serv. Res., $6(1), 20$

25. Stevens K.B., Spickett A.M., Vosloo W., Pfeiffer D.U., Dyason E. \& Du Plessis B. (2007). - Influence of dipping practices on the seroprevalence of babesiosis and anaplasmosis in foot and mouth disease buffer zone adjoining the Kruger National Park in South Africa. Onderstepoort J. vet. Res., 74, 87-95.

26. Sutmoller P., Thomson G.R., Hargreaves S.K., Foggin C.M. \& Anderson E.C. (2000). - The foot-and-mouth disease risk posed by African buffalo within wildlife conservancies to the cattle industry of Zimbabwe. Prev. vet. Med., 44 (1-2), 43-60.

27. Tenzin Dekker A., Vernooij H., Bouma A. \& Stegeman A. (2008). - Rate of foot-and-mouth disease virus transmission by carriers quantified from experimental data. Risk Analysis, 28 (2), 303-309

28. Thomson G.R. (1994). - Foot and mouth disease. In Infectious diseases of livestock with special reference to southern Africa (J.A.W. Coetzer, G.R. Thomson \& R.C. Tustin, eds). Oxford University Press Southern Africa, 825-852.

29. Thomson G.R. \& Bastos A.D.R. (2004). - Foot-and-mouth disease. In Infectious diseases of livestock (J.A.W. Coetzer \& R.C. Tustin, eds). Oxford University Press Southern Africa, 1324-1365.

30. Thomson G.R., Vosloo W. \& Bastos A.D.S. (2003). - Foot and mouth disease in wildlife. Virus Res., 91 (1), 145-161.

31. Vosloo W., Bastos A.D.R., Sahle M., Sangare O. \& Dwarka R.M. (2005). - Virus topotypes and the role of wildlife in foot and mouth disease in Africa. In Conservation and development interventions at the wildlife/livestock interface: implications for wildlife, livestock and human health (S.A. Osofsky, S. Cleaveland, W.B. Karesh, M.D. Kock, P.J. Nyhus \& A. Yang, eds). International Union for Conservation of Nature, Gland, Switzerland, 67-73.

32. Vosloo W., Bastos A.D.S. \& Boshoff C.I. (2006). Retrospective genetic analysis of SAT-1 type foot-and-mouth disease outbreaks in southern Africa. Arch. Virol., 151 (2), 285-298.

33. Vosloo W., Bastos A.D.S., Sangare O., Hargreaves S.K. \& Thomson G.R. (2002). - Review of the status and control of foot and mouth disease in sub-Saharan Africa. In Foot and mouth disease: facing the new dilemmas (G.R. Thomson, ed.). Rev. sci. tech. Off. int. Epiz., 21 (3), 437-449.

34. Vosloo W., Boshoff C.I., Dwarka R.M. \& Bastos A.D.R. (2002). - The possible role that buffalo played in the recent outbreaks of foot-and-mouth disease in South Africa. Ann. N.Y. Acad. Sci., 969, 187-190. 
35. Vosloo W., de Klerk L.M., Boshoff C.I., Botha B., Dwarka R.M., Keet D. \& Haydon D.T. (2007). Characterisation of a SAT-1 outbreak of foot-and-mouth disease in captive African buffalo (Syncerus caffer): clinical symptoms, genetic characterisation and phylogenetic comparison of outbreak isolates. Vet. Microbiol., 120 (3-4), 226-240.

36. Vosloo W., Dwarka R.M., Bastos A.D.S., Esterhuysen J.J., Sahle M. \& Sangare O. (2004). - Molecular epidemiological studies of foot-and-mouth disease virus in sub-Saharan Africa indicate the presence of large numbers of topotypes: implications for local and international control. Report of the standing technical committee of the European Commission for the Control of Foot-and-Mouth Disease, 12-15 October, Crete, 149-158.

37. Vosloo W., Thompson P., Botha B., Bengis R.G. \& Thomson G.R. (2008). - Longitudinal study to investigate the role of impala (Aepyceros melampus) in foot-and-mouth disease maintenance in the Kruger National Park, South Africa. Transbound. emerg. Dis., 56, 18-30.

38. Wooldridge M., Hartnett E., Cox A. \& Seaman M. (2006). Quantitative risk assessment case study: smuggled meats as disease vectors. In Biological disasters of animal origin. The role and preparedness of veterinary and public health services (M. Hugh-Jones, ed.). Rev. sci. tech. Off. int. Epiz., 25 (1), 105117.
39. World Organisation for Animal Health (OIE) (2004). Handbook of import risk analysis for animal and animal products. Vol. I. Introduction and qualitative risk analysis. OIE, Paris.

40. World Organisation for Animal Health (OIE) (2007). Chapter 2.2.10 - Foot and mouth disease. In Terrestrial Animal Health Code, 16th Ed. OIE, Paris, 110-121.

41. World Organisation for Animal Health (OIE) (2007). Section 1.3 - Risk analysis. In Terrestrial Animal Health Code, 16th Ed. OIE, Paris, 21-52.

42. Zepeda C. (1998). - Méthodes d'évaluation des risques zoosanitaires lors des échanges internationaux. In Seminar on safeguarding animal health in trade in the Caribbean, 9 December 1997, Port of Spain (Trinidad and Tobago). World Organisation for Animal Health, Paris, 2-17. 
